\title{
Amérique og den elegante 3. verden
}

Fransk-amerikanske relationer fra Baudelaire til Baudrillard

Identitet opstår og eksisterer i forholdet til »den anden«. For de franske intellektuelle har USA siden 1700-tallets revolutioner - den amerikanske og den første franske - haft en privilegeret plads som denne »anden«. Allerede under restaurationsperioden efter 1815 blev det klart for de nøgterne, at ingen alliance, uanset hvor hellig den var, på længere sigt kunne standse demokratiets, pengemagtens og rationalitetens nivellerende flodbølge. Politique rationelle kaldte Lamartine betegnende sit indlæg for almindelig valgret i 1831. Da grev Alexis de Tocqueville i de følgende år berejste USA for at indsamle materiale til modernisering af det franske fængselsvæsen, kom han hjem med et mere omfattende udbytte. De la démocratie en Amérique fra 1835 udtrykte en næsten religiøs overbevisning om, at demokratiet først og fremmest forstået som flertalsstyre og lighed - med uovervindelig kraft ville brede sig fra USA til Europa, uanset hvor energisk man forsøgte at kæmpe imod.

Tocquevilles USA-analyse var skelsættende. Dels fordi den udviklede sig til en af de første samfundsvidenskabelige teorier, der beskrev sociale forandringer som styret af objektive tendenser og kræfter, der var virksomme uafhængigt af menneskenes viden og vilje. Dels fordi den noget nær profetisk forudsagde, hvad der siden har været den lange trend $\mathrm{i}$ forholdet mellem USA og Europa: nivellering over for hierarki, lokalt selvstyre over for centralisme, det fri initiativ over for statslig styring, stemmeret over for fravær eller indskrænkninger af samme, pengemagtens rationalitet over for traditionsgivne systemer og normer, ytringsfrihed over for censur. $\mathrm{Og}$ bortset fra kortere periodiske afbrydelser har de amerikanske værdier ligget $\mathbf{i}$ offensiven.

Nivelleringens konsekvenser bekymrede den aristokratiske Tocqueville lidt, men som helhed stod han positivt over for den demokratiske omformning af samfundet. Anderledes synspunkter fandt man hos digterne. Efter Baudelaires opfattelse var det demokratiske USA ikke andet end »ét stort fængsel«, "ét stort gasoplyst 
barbari«, »én stor bogholderianstalt«. ${ }^{1}$ For ham var den fri meningsdannelse i USA »et tyranni meget mere grusomt og ubønhørligt end nogen monarks«: det er »meget svært at tænke og skrive i et land, hvor der er 20-30 millioner herskere«, i et land »uden aristokrati«. Bag »sin venlige frihedsmaske« giver demokratiet nemlig ikke rum for »individualiteternes udfoldelse«. Alle er i USA så manisk optaget af materiel virksomhed og så besat af »en naiv tro på industriens almagt«, at de ikke har tid til »at have medlidenhed med en digter, som smerten og ensomheden er ved at gøre vanvittig“. Han sigter her til Edgar Allan Poe: »I Paris, i Tyskland ville han let have fundet venner, som ville have forstået og trøstet ham «, i det gasoplyste barbari blev livet derimod en ørken for ham.

Baudelaire havde også et udviklingsperspektiv på USA. Det var det modsatte af Tocquevilles, og det var psykologisk-medicinsk, ikke sociologisk. Faderligt formanende og hovedrystende betragtede Baudelaire USA som en forvokset, vanartet kæmpebaby. Det er et "gigantisk og barnligt« land skrev han, "ungt og uformeligt«, "unormalt og næsten monstrøst«, og så tilmed »jaloux på det gamle kontinent«.

Uden at blive tendentiøs kan man vel nok sige, at det blev Baudelaires snarere end Tocquevilles USA-billede, der i eftertiden blev det mest udbredte blandt de intellektuelle. Formuleringerne blev mere sofistikerede og tankegangen mere filosofisk. Men det baudelaireske grundmønster har holdt sig forbløffende uforandret i disse lag helt op til vor tid.

På mere praktiske og økonomiske områder af samfundslivet forskød forholdet sig imidlertid mærkbart. Kæmpebabyen blev til rige onkel Sam, der havde så rart mange penge, at det ikke var til at klare sig uden. I første verdenskrig blev den afgorende franske krigsindsats hovedsageligt finansieret ved dollarlån. Og da krigen var forbi, blev dollarstrømmen suppleret med en vare- og kulturstrøm. Stumfilm, biler, klokkehatte, korte skørter, Charleston og »jazz musique« blev stilen, som borgerlige og mellemlaglige socialgrupper - bortset fra de intellektuelle - lappede i sig uden mange hæmninger.

Verdenskrisen kunne nok synes at være en krise for amerikanismen à la Wall Street. I Frankrig ligesom i Tyskland sugede hel- og halvfascistiske bevægelser med et dybt tag i de ubevidste længsler mange ind i deres maskeradeforsøg på historisk at regrediere tilbage til før plutokratiet, tilbage til autoriteten og hierarkiet. Andre grupper forsøgte derimod at springe åndeligt fremad med hjælp fra sovjetismens blanding af jern- og stålpoesi og NKVD-terrorens hemmelige gys. Men da den tredje store drømmefabrik, den amerikanske, flyttede fra 
nabolaget af Wall Street til Hollywood begyndte de celluloidstrimlede kærlighedsamericana at beruse den europæiske massebevidsthed endnu mere end nogen rigmandsdrømme tidligere havde gjort. ${ }^{2}$ Alt foregik nu i masseformationer. Men der var psykohistorisk forskel på at fascineres af formationer af lårsvingende korpiger, af kolonner $\mathrm{i}$ strækmarch eller af oplinede stødarbejdere fra traktorfabrik nr. 37. $\mathrm{Og}$ for den individualistiske indlevelse: Fred Astaire dansende foran lårsvingerne eller Friedrich Goebbels råbende foran støvlesvingerne.

Da krigen var ovre, forenkledes valgsituationen. Den kommunistisk organiserede arbejderklasse fortsatte i sin årtier lange drøm om et Stalingrad, senere Volgograd ved Seinen. Men i den øvrige brede bybefolkning stod amerikanismen naturligvis stærkere end nogensinde før. Venlige intellektuelle kunstnere som Jacques Tati kunne med mild ironi satirisere over det hektiske tempo i kommunikation og trafik, som efter evne blev importeret fra »over there «. ${ }^{3} \mathrm{Og}$ statsintellektualismen kunne gøre puristiske forsøg på at forbyde den amerikanske sprogforurening fra ord som »drugstore«, »stop«, »parking « o.m.a., der i en mærkelig fransk-amerikansk blandingsudtale ustandselig trængte sig ind i sproget. Men selv med antiamerikanisme, sprogpurisme og nationalisme funderet i et statsapparat, hvor enevældens bureaukratiske centralisme regerede videre $i$ en kun let moderniseret udgave, kunne tendensen ikke standses. Forretningsmanden måtte naturligvis forkrome sin succes ved at købe sig et dollargrin og efter bedste evne tillægge sig en »easy going« og »businesslike« livsstil, der forplantede sig nok så godt som statshabitternes. Dog ikke til de intellektuelle.

De Gaulles nationalt genrejste Frankrig, landet uden Ford og GMfabrikker, forsøgte som svar på »le défi américain « ${ }^{4}$ sin egen model, en kompromisdannelse med amerikanismen, som man kunne kalde »supermoderne à la française«. Hjemmelavede atomvåben, rumraketter og satellitter, Caravelle-, Mirage- og Concordefly, Bull-computers og til menigmands beundring og nationale afstivning et lokalt skyskraberkvarter i Paris omringet af en motorgade, hvorfra man på passende afstand kunne besigtige denne offentligt initierede udstilling af forretningsfrihedens og modernitetens monumenter. Sjovt nok hed kvarteret »la Defense«. Det bedste forsvar er angreb, siger militaristisk-absolutistisk statsraison. Men man kan ligesåvel komme til at tænke på det psykologiske fænomen, som hedder identifikation med aggressor.

Den franske intelligens' placeren sig i den nationalt farvede modernitetsproblematik, som USA-forholdet har været den offensive faktor i, har været præget af, at det intellektuelle liv siden enevælden har 
været tæt forbundet med statsmagten. Via det elitære uddannelsessystem og en centralistisk universitets- og forskningsorganisering er de intellektuelle blevet holdt tæt til magten uden dog at have fået mere end en lille bid af den. Deraf de hyppige udbrud af "magtkritik « $i$ åndslivet, drevet af en følelsesintensitet, som er svar at forstå uden denne baggrund. ${ }^{5}$ Deraf også partikommunismens forbløffende udbredelse $\mathrm{i}$ de kritiske intellektuelle lag ikke mindst før 68. Med en tænke- og følemåde formet $\mathrm{i}$ det franske statssystem har det for de kritiske været nærliggende at fantasere sig til et alternativ af sovjetisk tilsnit: bemandingen af apparatets »couches dirigeants« og den folkedemokratiske målsætning ville være ny, men bureaukratismen og centralismen ville naturligvis være den gammelkendte, blot løftet op på et intensiveret, totalt plan, i og med at det private erhvervsliv blev likvideret. Heraf så også i den modsatte lejr den næsten hadefulde antisovjetisme og antitotalitarisme, og den stadige reference til Solsjenitsyns Gulag-mareridt. Man kender typen af system indefra, deltager måske i det, og projicerer sit undertrykte had og sit autoritære oprørsbehov ud i et spejlvendt fjendebillede. De autoritæres antiautoritære oprør i et scenario garneret med esprit og selvalvorlig magtfilosofi, men med stor tiltrækningskraft over for ăndsbeslægtede i andre lande. ${ }^{6}$

Den franske autonomiforestilling er blevet holdt oppe af denne tofløjede negation vendt mod både øst og vest. Mens man mod øst forsvarer individualismen og friheden $i$ en ubændig, oprørsk attitude - den selvmorderisk dristige David med sin "force de frappe« -, er det mod vest den hofmandsagtige holdning, man indtager. Over for det amerikanske barbari og simili føler franskmændene, at de repræsenterer kulturen og åndslivet, som årgangsvin over for californiske druer, Versailles over for Hearst Castle. Holdningen har præget officiel fransk udenrigs- og kulturpolitik, der op til 80'ernes socialistiske regering har iscenesat denne tematik med teatralsk højtidelighed. Men det har også gennemtrukket det mere uofficiøse kulturliv, der på alle mulige felter, men ikke mindst $\mathrm{i}$ filmen, har måttet bearbejde amerikanske udfordringer. I næsten alle tilfælde har franskmændene trukket sig tilbage $\mathrm{i}$ en forbeholden distance og trofast insisteret på en »fransk « bearbejdning af modernitetens problemer, uanset hvor amerikanske disse har været $\mathrm{i}$ oprindelse og fremtræden.

De mest interessante resultater af sådanne fransk-amerikanske processer er måske fremkommet inden for det filosofiske og kulturanalytiske felt. 50 'ernes og 60 'ernes franske strukturalisme kan meget vel opfattes som en moderniseret humanismes modsvar til de sociale forandringer, som fra USA rykkede ind over Vesteuropa i den samme. 
periode: et farvel til historisme og forestillinger om absolutte menneskelige værdier, om fremmedgørelse, om essens og autenticitet m.v. Et velkommen til en nøgtern, antitragisk og relativistisk beskrivelse af de menneskelige fænomener som systemernes upersonlige fungeren.

Alligevel var det et meget kontinentalt, europæisk og fransk svar. Mens samtidig amerikansk strukturalisme fascineredes af at systembeskrive ad hoc-agtige, afgrænsede mikrosammenhæng, rakte de franske analyser ud efter at blive totalanalyser, der i sidste ende tenderede til at forankre sig i transcendentalfilosofiske hypoteser. Tydeligt således Lévi-Strauss' forestillinger om de universelle grundstrukturer i den menneskelige ånd. Greimas' senere teoribygning fra 60 'erne gik med sine intentioner om entydighed, hierarki og kohærent totalitet langt videre $\mathrm{i}$ sin systemsøgen. Bortset fra at det med sin kombinatorik er umådeligt mere raffineret end som så, ligner beskrivelsesapparatet på et idealplan en 1700-tals klassifikatorisk teori af typen Linné.

Også en sammenligning af den amerikanske og den franske Freudbearbejdning i perioden viser filtrenes forskellighed: over for den amerikanske ego-psykologis pragmatiske og optimistisk subjektorienterede terapiintentioner kom Lacans ubønhørlige symboliseringsprocesser beliggende forud for og hinsides enhver bevidst ændringsmulighed. Og selv hvor franske strukturteorier som hos Cl. Bremond direkte mimede den ny computerteknologis digitale logik, lå der i den franske udgave en undertone af skæbnebundne lovmæssigheder, som var meget forskellige fra den fornemmelse af uendelig kombinatorisk frihed, mulighedsmangfoldighed, som prægede de amerikanske versioner af den samme logik. ${ }^{7}$

Måske var det derfor heller ikke tilfældigt, at det først blev den "poststrukturalistiske« Derrida og den mere impressionistiske, "sene« Barthes, amerikanerne følte sig kongeniale med. Derridas opgør med »to tusinde års vestlig metafysik « var ganske vist meget kontinentalt ved sin systematiske strenghed og ved sin mildest talt esoteriske diskurs. Men bortset herfra kunne man se grammatologien som et radikalt filosofisk modstykke til, hvad der var levet erfaring i 60'ermoderniteten på begge sider af Atlanten. Når Derrida afslørede essens-, transcendens- og autenticitets-(nærværs-)forestillinger i selv den mest teknificerede humanvidenskabelighed - den strukturelle sprogvidenskab - gav han dødsstødet til de sidste overlevende rester af totalteorier, absolutte værdier og hierarkier. Hans forestillinger om betydningerne som alene produceret af udtryksforskellenes uendelige 
kombinatorik, »le jeu des signifiants«, havde karakter af en spilteori aftegnende et decentreret, postmoderne univers.

Derrida var ikke i sig selv amerikaniseret, selv om han var inspireret af den amerikanske semiotiker Peirce. Men han var tankemæssigt à jour i forhold til den dybdeløse flade, der udbredte sig for det intellektuelle øje, da Warhols suppedåse afløste den efterhånden mere og mere officiøse 50'er og 60'er-modernisme: da Munchs »Skriget « blev sofastykke i de tusind hjem. Mens Derrida derfor blev fransk eksportartikel og adapteret i den amerikanske dekonstruktion, stod den franske hjemmefront desillusioneret tilbage, berøvet først eksistentialismens værdiforestilling om Mennesket, derefter strukturalismens rationalistiske systemtro og til sidst op i 70'erne også fremtidshåbet $\mathrm{i}$ de politiserede filosofier efter 68 .

Opgøret med det politiske projekt blev anliggendet for de såkaldte »nye« filosoffer. Men stemningen af at være ankommet til en grundlæggende desillusions "post«-tilstand blev mere og mere udbredt $\mathrm{i}$ slutningen af 70'erne. Det politiske projekts troværdighedsforfald var ikke mere kun en højrefløjspåstand, men blev generelt oplevet som en kendsgerning. En filosof som J.-F. Lyotard havde tidligere indrulleret sig under det programmatiske alternativ "Socialisme ou barbarie«. $\mathrm{Nu}$ mente han heller ikke, at et sådan alternativ eksisterede mere. Uden vel direkte at sige, at det var barbariet, han så bekendte sig til, forskød fascinationen sig fra socialismens utopier til mystikken bag det givne som uafkasteligt vilkår.

En central tematik i situationsopfattelsen efter de gamle, nu påny afdøde forestillinger om mening blev reformuleringen af det evigt uløselige forhold mellem væren og bevidsthed, sproget og virkeligheden. I Frankrig refererer man i de filosofiske og humanvidenskabelige skrifter sjældent til de skribenter, man polemiserer imod, endnu sjældnere til dem, man trækker på, især hvis de endnu lever. Der er derfor naturligvis ingen Derrida-referencer, når Baudrillard i Simulacres et simulation formulerer en opfattelse af sprog-virkelighedsforholdet, der trods forskelle i over- og undertoner er meget beslægtet med Derridas 10-15 år tidligere afskrivning af et ethvert uformidlet nærvær og enhver transcendens hinsides betydningsproduktionen. Terminologien er blot en anden og sigter direkte på forestillingen om virkelighedens eksistens: "når kortet dækker hele territoriet, forsvinder sådan noget som realitetsprincippet «. ${ }^{8}$ Tegnene repræsenterer ikke mere tingene, men opsuger dem; transcendens og realitet flyder sammen og bliver til en »hyperrealitet«. Virkeligheden er alene den lighed, som kan findes mellem et ansigt og dets spejlbillede, og at ville bryde ud af ligheden i spejlrelationen vil være forgæves. 
Når man ser på tematikken og forløbstendensen i de post-politiske filosofier fra slutningen af 70'erne og begyndelsen af 80'erne, kan man med næsten matematisk nøjagtighed beregne, at USA-fascinationen snart ville komme på dagsordenen igen. Ikke 68 -solidariseringen med det »andet USA «, de politiske bevægelser og syreeksperimenterne. Men en optagethed af »the real thing «: det store gedigne »main stream«-USA som livsform, som selvbekræftende virkelighed.

Da revolutionshåbet skrantede i slutningen af 70'erne, slog mange europæiske intellektuelle sig desperat på den utopisk-messianske Ernst Bloch og lærte sig derudover italiensk for at kunne følge med i støvlelandets politik, hvor der som det sidste sted endnu syntes at være spark i arbejderklassen. Men da de italienske centrumalliancer blev stærkere og terrorismen begyndte at blive ene om at repræsentere radikale venstresynspunkter, slukkedes ogsă denne sidste ledestjerne.

Kyniske, ribbede for forestillinger om, at fremtiden ville bringe andet en kapitalisme, kapitalisme og atter kapitalisme, gav man sig da til at se uhyret lige i øjnene. De europæiske intellektuelles valfarter til yuppiernes regenererede Reagan-USA begyndte. Det førte til mange rejserapporter. På et tidspunkt måtte der også komme en spektakulær bog ud af det reorienterede rejseliv. Man kan undre sig over, at den først kom i 1986 med Baudrillards Amérique. Men man behøver ikke undre sig over, at den så kom fra den franske »post«filosofi. Disse »begærs«-folk havde fra starten omgåedes »oplyserne« Marx og Freud med ekstrem respektløshed, var snarere nietzscheanere. Og allerede deres postmoderne udkast fra 70'erne var langthen en kryptografisk tematisering af det amerikanske. I Amérique knytter Baudrillard åbent enderne sammen, når han bekender: »Amerika er hverken en drøm eller en realitet, det er en hyperrealitet", USA er det perfek te simulakrum, et gigantisk hologram - den realiserede utopi. ${ }^{9}$

Den tematiske konstans skal imidlertid ikke skjule, at der foregår en omvalorisering undervejs. 70'ernes franske postmoderne var tidligt ude og langt fremme med afskrivningen af de store "meningssystemer « og med den betingelsesløse accept af »den tredie simulakrumorden «, hvor transcendens og realitet flyder sammen. Men der har hele tiden, ikke mindst hos Baudrillard, tydeligt kunnet høres en klang af våndefuld identifikation med aggressor: den simulakriske totalopsugning af den sidste mening og realitet blev besunget og besværget i skingre toner fra grænseområdet mellem fryd og smerte, mest det sidste. I Amérique brydes modstanden imidlertid, og i løbet af bogen fuldbyrdes hengivelsen til »den eneste dybe lyst: at cirkulere« 
i det amerikanske livs flyden, hvor kroppe og kommunikationer transporteres omkring i bløde teknologier. Kapitulationsbevægelsen kan aflæses inde $\mathrm{i}$ selve bogens forløb. Den foregăr rykvis og med systematiske tilbagefald. Men den foregår.

Ligesom hos Baudelaire bliver orkenen en central metafor $\mathrm{i}$ Baudrillards USA-oplevelse. At gennemkøre de amerikanske ørkener er at opleve et "æstetisk " og "extatisk" billede på "den sociale udtømning «. Den er asocial og overfladisk, dens geologi er et katastrofisk, ironisk varsel om det sociale livs tilbagevenden til det uorganiske. Farten gennem ørkenen er »virkningens triumf over årsagen«, molekylernes acceleration i varmen et subtilt tab af mening. Den amerikanske rejses centrale spørgsmål bliver: "hvor langt kan man gå i udslettelsen af meningen, hvortil kan man fortsætte i den ørkenagtige irreferentielle form uden at revne og samtidig fastholde forsvindingens esoteriske charme?

Bevægelsen gennem ørkenrummet er en opsugning i det. Modstanden er væk, ligesom i atomreaktoren: den udfolder heller ikke nogen »rumlig penetrationsenergi«, men »driver sig selv frem ved at skabe et tomrum foran, som opsuger den«. Figuren bliver fortsat senere i en fascineret skildring af at befinde sig i bilstrømmen på de freeways, der gennemkrydser Los Angeles: de individuelle destinationer forsvinder, og man opsuges i en rituel proces, "ren statistisk energi«, den uendelige kollektive cirkuleren, »unyttig og gloriøs«.

Bortfaldet af »penetrationsenergien $\ll$ og de individuelle destinationer har at gøre med, at individerne autoreferentielt forbindes med sig selv i lukkede kredsløb, bliver til monader i den sociale strøm. Når folk løber marathon i New York sker det ikke i en omverdensbesejrende »prometheusk ekstase«. Det er en »autistisk performance« uden anden konsekvens end den blotte eksistensbekræftelse: "I did it!« Denne autistiske selvrefereren gentager sig i apparatlivet. Teen-ageren med sin walkman eller sin video er forbundet med sig selv i et lukket barn-maskine-kredsløb. Den intellektuelle med sit tekstbehandlingsanlæg jagter sin egen hjernevirksomheds millioner af forbindelser bredt ud på skærmen som et videospil. Og i det seksuelle register rendyrkes selvreferencen hos body-builder-kvinden, som ved optræning af vaginalmuskulaturen er nået til selv at kunne reproducere den mandlige penetration. Kønsforskellen forsvinder som hos kønsubestemte idoler som Boy George og Michael Jackson eller bliver til en stil, et spil, et look: kønnet bliver et individuelt forehavende, der henviser til sig selv, kønsforholdet i det hele taget til et sekundært fænomen hinsides gammelmodernistisk seksualfrigørelse. Berøring er noget, man køber sig til på særlige institutter, kontakt er en aseptisk 
informationsoverførsel. Kroppene kommunikerer deres kønsvæsker til hinanden uden forførelse eller andet besvær.

Indbegrebet af selvisolation og selvreferentialitet er dog joggeren, der med walkman for ørerne, vægtbælter om livet, vægte i hænderne, skum om munden og vilde øjne løber ud ad stranden uden at kunne standse eller standses, alene opslugt af at udtømme kroppen som et helligt offer. USA er nemlig en anorexi-kultur, der homøopatisk besværger tidligere tiders mangelsamfund ved en altomfattende diætetik: "Low tar. Low energy. Low calories. Low sex. Low speed «. "Kroppen bliver kærligt plejet i den perverse vished om, at den er unyttig«. At gå eller på anden måde benytte kroppen med et formål er forbeholdt immigranter fra den 3 . verden. For amerikanere er muskelbevægelse en serviceydelse, man køber i et motionsstudie »med forkromede trisser og forfærdende medicinske proteser«, hvorfra der går en lige linie tilbage til middelalderens torturinstrumenter.

På den ene side er USA en lasket og overfyldt kultur, tømt for appetittens dynamik og plaget af spørgsmålet: »Hvad skal man gøre, når alt er disponibelt ...? « Kroppen er f.eks. ikke mere en lystkilde i denne »totale disponibilitets« obskønitet. På den anden side gøres kroppen til genstand for en ensom og energisk omsorg og for en »formens og hygiejnens exorcisme« med det formål at præservere »en utopisk ungdom« $\mathrm{i}$ en kamp mod døden, hvis eneste mening er at blive forebygget. Forebyggelsen bliver derved til en forudgribelse: "Den omsorg, man drager for den levende krop, forudgriber sminkningen i the funeral homes, hvor smilet kobles på døden«.

Ensomheden og selvreferentialiteten modsvares af et tilsvarende større afhængighedsforhold til det sociale forsyningssystem. »Det er nødvendigt, at alt fungerer hele tiden, der må ikke være nogen afbrydelse i menneskets kunstige magt, afbrydelserne i naturcyklerne (årstiderne, dag og nat, det varme og det kolde) må ophæves til fordel for et funktionelt kontinuum, der ofte er absurd «. Lysene brænder i kontorskyskraberne og på vejene dag og nat, fjernsynene og air condition-anlæggene går på de tomme hotelværelser og dåselatteren følger alt på tv bortset lige fra nyhederne, børskurserne og vejrudsigten. Selv den »afbrydelse«, den forskel, der er mellem sandt og falsk, godt og ondt accepteres ikke rigtigt: alt er sandt og alt er godt.

I det berømte hotel Bonaventuras arkitektur har man fået ophævet selve indre/ydre-adskillelsen, alt spejler kun omgivelserne i et "spatio-temporelt« spil mellem transparens og brydning. På samme måde skjuler menneskemonaderne på gaden sig bag reflekterende solbriller for at undgå kontakt, der kan føre til truende udladninger fra de andres indre voldspotentialer: »Walkman, sorte solbriller, automa- 
tisk elektronisk husholdning, vogn med mulitikontrol og helt ud til den evige dialog med computeren ender alt det, man pompøst kalder kommunikation og interaktion, i hver enkelt monades tilbagetrækning til sin egen formels skygge, til sin selvstyrede niche og kunstige immunitet «.

Således ser det ud: »universet efter orgiet, efter socialitetens og seksualitetens krampetrækninger«. D.v.s. efter penetrationslidenskaben for penge, succes, hårde teknologier og efter Woodstock-korstoget mod det hele. Det er »afintensivering, decentrering, klimatisering og bløde teknologier. Det er paradis. Men en let modifikation, lad os sige en drejning på nogle grader er nok til, at man kan forestille sig det som helvede«.

Hvis man ellers kunne have næret tvivl, må den her være forsvundet. Det er en europæisk intellektuel, der analyserer, med tankeapparatet fuldt af kontinentale kategorier. Beskrivelsen af USA som modernitetens »vilde《 og »naive« land genklinger af Baudelaire-traditionens kulturelle mereværdstematik. Meningsudtømningen i den stadige cirkuleren og differensernes ophævelse i komfortens sofabløde kontinuum indeholder en kritik sammenføjet af elementer fra 1800tallets meningssystemer, som senere er gået videre ind $i$ både venstreog højrefløjenes kulturkritik. Frankfurterskolens bl.a. Det er Freuds og Frankfurterskolens linie til egopsykologien m.v., der fornemmes i lokaliseringen af, hvordan individisolationen fører til irrationel angst og tvangsmæssig dependens af det sociale forsyningssystem, der uden afbrydelse skal bekræfte en vaklende eksistensfølelse. Fra neofreudianske narcissismeteorier stammer analysen af penetrationsenergiens forfald, d.v.s. overgangen fra Prometheus, der ville stjæle ilden fra guderne, til individet som en afintensiveret, autistisk monade med walkman. Og livet som én stor forebyggelse af forfaldet og døden ligger meget tæt op ad Ariès' mentalitetshistoriske analyse af døden på amerikansk facon. ${ }^{10}$ Endelig har hele det kritiske analysekompleks fået luft under vingen med hjælp fra semiotikkens analogiserende og associative spring gennem store strækninger af tid og rum.

Netop som man således synes, at Baudrillard begynder at falde på plads i en semiotisk, postmodernistisk frankfurterismes uvilligt tragiske USA-billede, begynder hans optik at dreje. Det sted, hvorfra billedet er set, dukker på Bonaventura-vis op som spejlbillede i den reflekterende USA-overflade. Og snart er det Europa, som han og læseren - delvis ubevidst - sidder og ser på. Vinkelen er bl.a. historisk: USA viderefører i lige linie det 17. og 18. århundredes enkle, effektive forestillinger om utopien og moralen, hedder det. Troen blev hos de eksilerede sekterister, som rejste til Amerika, til praktisk mo- 
ral, og USA blev simpelt hen den realiserede utopi. Imens drejede Europa ind i »den borgerlige model fra 89 og denne models uendelige forfald «, d.v.s. ind i det 19. århundredes teatralske, nostalgiske utopi om revolution, fremskridt, frihed: idealet, som vi hævder kan realiseres, men som aldrig er blevet det, og som vi ved sygner hen, inden det nogensinde kommer dertil. Heraf den europæiske melankoli.

Mens den konkrete forestilling om lykken og om moralen som adfærdsnorm forblev levende i USA, lykkedes det det 19. århundredes Europa, med Marx i spidsen, at få likvideret al den slags og få det afløst af begrebet om den »objektive« historiske udvikling. Men kapitalen er altid en fase forud for den marxistiske analyse, den forstyrrer dialektikken og vil ikke følge »historiens « spilleregler. Kapitalismen må derfor altid rekonstrueres teoretisk bagefter, og revolutionen bliver noget, som kunne have været der, men aldrig var det. Det passer imidlertid godt til europæisk tankegang, der mener, at alt kulminerer i transcendensen, og at intet eksisterer, som ikke har været tænkt i sit begreb. Omvendt i Amerika. Her drejer det sig om »ikke at begrebsliggøre virkeligheden, men virkeliggøre begrebet og materialisere ideerne«: »i Europa er selv materialismen kun en idé«. $\mathrm{Vi}$ er fanget i tanken om universalitet, transcendens og centralisme og kan ikke decentrere os, gøre os praktisk fri, konkrete, fleksible, funktionelle. »Amerika er den originale version af moderniteten, vi er den eftersynkroniserede eller undertekstede version«.

Baudrillard forsøger - med en for ham typisk trelagsmodel - at sætte den mentale forskellighed på begreb: USA bevæger sig på »første« niveau - det »primitive« og »vilde« - og på det »tredje« det absolutte simulakrums niveau. Europæerne har derimod altid foretrukket det "andet" niveau: refleksionen, spaltningen, ironien, den ulykkelige bevidsthed. Analysen er ikke indgående, kan man sige. Men taget som den er, signalerer den genkendelse.

Mere provokatorisk bliver fremstillingen, når denne europæiske selvrefleksion bevæger sig ind på det politiske felt, hvor modstandsmekanismerne traditionelt er stærkest. Det har både i Frankrig med althusserianismen og i det tysk-danske rum med kapitallogikken m.v. været god latin at mene, at »freedom « på amerikansk kun var et "Schein«: bag den tilsyneladende frihed til hvad det skulle være, lå $i$ virkeligheden altid onkel Sams \$-tatoverede jernnæve, der restløst styrede de forblindede individer, som var de somnambule dukker, hvis eneste ubevidste mål var at realisere det pengeøkonomisk rationelle. Eller omvendt $\mathrm{i}$ andre psykologiske teoritilbygninger: individer i senkapitalismen er hjælpeløst infantiliserede narcissister med melago- 
mane forstyrrelser, der stiller sig i vejen for en »realitetsadækvat" adfærd. Fælles for begge tilgange er determinismen: det vestlige menneske er en automat, en slave, hvad enten det er af kapitalen eller af sin kapitalstyrede psykologi.

Det er behovet for at kaste disse åg af sig, der slår igennem, når Baudrillard bryder overtværs og med nogle postmodernistiske herresving kontrasterer: „Vi er frie $\mathrm{i}$ ånden, men de er frie i deres bevægelser«. De er vulgære og banale, men »easy« og aldrig latterlige. Latterlig er den europæiske frihed og lighed som prætention og tunge politiske slagord. Amerikanerne derimod realiserer en praktisk frihed over hele registeret: »frigjort er det menneske, som skifter position, som cirkulerer, som skifter køn, klæder, adfærd efter moden og ikke efter moralen, som skifter mening efter meningsmodeller og ikke efter samvittighed «. Fra revolutionsterroren til 68 har vi drømt om den store værdiudjævning og i eruptive revolutioner lejlighedsvis forsøgt at realisere den - uden held. I Amerika foregår den bare, »på en empirisk og vild facon«. Introverte som europæerne er, kan de ikke forstå det amerikanske systems fundamentale udadvendthed. Virkeligheden er et mysterium for dem, "nøjagtig som varen var det for Marx: en hieroglyf for den moderne verden, mystisk fordi den netop vender udad, en form, der realiserer sig i sin rene fungeren og i den rene cirkulation (hej Karl!) «. Den er banal og vulgær, men »alle vore analyser med begreber om fremmedgørelse, konformitet, ensretning og dehumanisering falder af sig selv: ved synet af Amerika er det dem, som bliver vulgære«. Og som en frafaldens replik til den tidligere konklusion hedder det nu: »Det er paradis (...) undertiden dystert, ensformigt og overfladisk. Men det er paradiset. Der er ikke noget andet $\ll$.

Om ikke før står det på dette tidspunkt klart, at Baudrillards bog ikke handler om USA, men om den europæiske intellektuelles oplevelse af USA i disse år. Alt sammen foregår på europæerens indre skærm, en »virkelighed « er næsten umulig at uddestillere og skille fra, hvad der er projektion. Et banalt eksempel fra en af bogens USAkritiske analyser kan illustrere.

Den europæiske intellektuelle kan f.eks. - tit fra egen social baggrund - have de forudgående generationers fysiske slid som et endnu traumatisk erindringsbillede. Urbanitetens fysiske inaktivitet i polstrede sidde- og liggemøbler er ham en kilde til uophørligt behag. Han suger hvilen ind efter århundredernes slid på marker, værksteder og fabrikker. For ham udløser mødet med den amerikanske jogging- og kropskultur intenst besatte associationer til oplevelser af motorisk udfoldelse som en viljens lidelsesfulde drab på kroppen eller 
til det 3. århundredes søjlehelgener. Et socialt fænomen vælder frem med betydningsfylde.

For objektet, de joggende PG-atleter og managementdesignere, er aktiviteten derimod formentlig ikke meget mere end en hygiejnisk foranstaltning over for kroppen på linie med, hvad tandbørstning er over for tandsættet. En gammeleuropæer, der milieumæssigt måske er dybt fortrolig med kropslig nedslidning og forfald, læser i det hele taget den amerikanske interesse for kropspræservering som et perverteret, dybt dekadent forhold til døden. Ikke f.eks. som led i en social udvikling frem mod en udvidelse af livsmulighederne og en forlængelse af kroppens sociale holdbarhed.

I den del af Baudrillards beskrivelse, hvor de gedigent »europæiske« analyser aktiveres, bliver USA et billede på alt det fremmede, fremtidige, truende, opløsende $\mathrm{i}$ forhold til, hvordan en europæisk bevidsthed er indrettet. Efter at dette billede er bygget op med behørig gysen og fascination, kaster han det selvrefleksivt tilbage på de typisk europæiske bevidsthedsstrukturer: på idealismen også i de filosofiske felttog til dens angivelige bekæmpelse, de nederlagsviede revolutionsforestillinger fra det 19. århundrede, den permanent ulykkelige bevidstheds blanding af utopi og nostalgi etc. Det er en moderne, spejlfordoblet udgave af en gammel model, fransk og oplysningsfilosofisk: Montesquieu's Lettres persanes. Skønt essayistisk kursoriske er disse »lettres américaines « så probat Europa-kritiske, at det kan tage sig masochistisk ud. Og dog er det ikke netop en psykisk tilbøjelighed blot der er på færde.

Bogen er skrevet i disse års krydsningspunkt mellem en europæisk tanketraditions kriseagtige nedtur og en modernitetsbølge, der måske for første gang slår så højt ind over den europæiske intelligens, at ikke engang hovedet mere er oven vande. Også fodfæstet kniber det med i dette skred af rullende sten. Men godt det samme. Ved det lys, bogen kaster tilbage på de tidligere bøger i forfatterskabet, viser den nemlig, at selv en Baudrillard trods alle forvirrende signaler om det modsatte hidtil har været solidt plantet i den franske og europæiske tradition. Især i den værdiorganisering, som har ligget intakt neden under den tilsyneladende ultramoderne simulakrum-problematik. Først mødet med »the real thing «, hyperrealitetens USA, det fuldstændige simulakrum og den realiserede utopi får også værdigrundlaget til at vakle. Postmodernitetens turbulens er hidtil blevet ind- og omkredset som et vilkår, uafviseligt, men egentlig ikke som mere attraktivt end svimmelhed. I den chokagtige indsugning i den amerikanske cirkuleren bliver meningstømningen til en euforisk frihedsfølelse, svimmelheden til en lystfyldt svæven. Men hvor længe varer den? 
Chokvirkninger fortager sig som regel. Tilbage står derfor stadig situationen: de gamle modeller er udslidte tragedienner, og en ny sensibilitet har stadig hårdt brug for kompatible tankestrukturer at bevæge sig i. Det redskab, der ligger nærmest for hånden, er »USA«. Vi tænker vores eget modernitetsproblem igennem USA-billeder. Til det formål er der gode billeder i Baudrillards galleri, hvis man kan finde en kurs mellem de defensivt dystopiske og de sanseløst euforiske. Det kan han ikke selv. Han fremstiller problemet, ikke dets løsning.

Hvordan står det i øvrigt til med de rigtige, levende amerikanere? For dem ser situationen helt anderledes ud. Mens vi længes efter lethed og cirkulation, længes de efter »roots« og tradition, eller rettere tegnene derpå. Europæiske årgangsfilosofier til de intellektuelle, franske slotsaftapninger og Mercedes-biler til de købedygtige. Lige så mange europæere, som ønsker at fortabe sig i det fluidum kaldet California, lige så mange amerikanere vil hellere end gerne bruge ugevis på at gennemsøge nordsvenske kirkebøger for at finde navnet på en Nilsson, som de kan tro, de nedstammer fra. Sådan er problemerne så forskellige.

Dog skal man ikke udelukke, at det endnu en tid vil være nemmere at finde en Nilsson end at fa en europæisk intellektuel til at cirkulere, udstyret med en tanketype, der kan tåle bevægelsen. Det kan Baudrillards nemlig ikke. Den kan percipere og producere en buket af relevante betydninger ud af USA-Europa-differensen. For så vidt kan denne franske fortrop bidrage til at overvinde "den mangel på gnist, der er i vores modernitet«: »vi gør os kun uvilligt moderne og indifferente«. Men der skal mere »power« og »rigueur« til, hvis vi skal dementere den amerikanske Europaopfattelse, som Baudrillard citerer en vis I. Huppert for: »De misunder os givetvis, og de beundrer vores fortid og vores kultur, men i grunden forekommer vi dem at være en slags elegant 3. verden«.

\section{Noter}

1. Disse og de følgende Baudelaire-citater stammer fra hans Poe-essays »Edgar Allan Poe, sa vie et ses ouvrages«, »Edgar Poe, sa vie et ses œuvres« og »Notes nouvelles sur Edgar Poe«, i Baudelaire: Euvres complètes, (l'Integrale), Paris 1968, p. 319-353.

2. Før børskrakket i 1929 var rigdomsfantasier almindeligere på film end efter, hvor kærligheden - tit netop på tværs af grænsen rig/fattig - fik en ubestrịt førsteplads i de tematiske vardisystemer. En sammenligning af f.eks. forholdet mellem Chaplins »Guldfeber « (1925) og »Byens lys« (1931) og »Moderne tider« (1936) viser skiftet. Efter 29 var rigdommen som fattigmands mulighed så sociologisk usandsynlig, at den som regel blev indføjet ved hjælp af forvekslingsmotivet: rigmanden der for et kort stykke tid bytter rolle med bumsen, et motiv der optrader i et utal af film. 
3. Klassisk og uovertruffen $i$ »En festlig dag《 fra 1947.

4. Titlen på Servan-Schreibers debatbog fra 1967.

5. Der tænkes her først og fremmest på Foucault, men der kan fremanalyseres mange andre eksempler på nihilistiske, anarkistiske eller på andre måder »magtkritiske« tendenser i undergrunden af fransk filosofi og teoridannelse.

6. Jørgen Schleimann, Henrik Stangerup m.fl. for at nævne danske eksempler.

7. En fuldstændig tilsvarende forskellighed ses i periodens avantgardistiske kompositionsmusik: de europxiske eksperimenter gik ud på at udvikle systemer, hvorfra man med matematisk nøjagtighed kunne forudberegne og skematisere det tonale forløb, de amerikanske derimod fascineredes af kombinatorikkens frihed. Cf. Gyldendals Musikhistorie, bd. 3, Kbh. 1984, p. 2l2ff.

8. Simulacres et simulation, Paris 1981, p. 183.

9. Dette og alle de følgende citater er oversat direkte fra Amérique, Paris 1986. Under færdiggørelsen af denne artikel udkom den danske udgave af bogen, Amerika, Kbh. 1987. Dens oversættelse er absolut ikke fri for fejl, deriblandt nogle påfaldende sådanne, og den er tit ikke pracis i forhold til originalen.

10. Se Philippe Ariès: L'homme devant la mort, Paris 1977, afsnittet »Le cas américain«, p. 589 ff. 